\title{
Perspectives on the doctrine of providence in some of Calvin's sermons on Job
}

\author{
Pieter C Potgieter \\ Faculty of Theology \\ University of the Orange Free State
}

\begin{abstract}
Perspectives on the doctrine of providence in some of Calvin's sermons on Job

It is quite remarkable that Calvin addresses himself to the providence of God not only in his 'theological' works (eg Institutes), but particularly also in his more 'popular' works, for instance his correspondence and sermons. This is where the doctrine of providence is significantly contextualized. It is obvious that he takes up his topic in a most responsible manner, by which the 'providentia Dei' should not only comfort those who believe in Christ, but should also call for a responsible life before the countenance of God. Furthermore, for Calvin providence is not so much an issue to be 'explained', but rather a 'confession' related to the very heart of faith.
\end{abstract}

\section{INTRODUCTION}

In a period of extreme religious, social and political turmoil (1554-5), Calvin preached 159 sermons on the book of Job. In these sermons the providence of God is evident as a continuous line of thought. I have examined eight of these sermons for the purpose of this paper. In selecting these, I have been led by Scripture references regarding the providence of God which often recur in theological literature, viz Job $1: 12,21 ; 2: 10 ; 5: 17,18 ; 4: 15 ; 31: 1-4 ; 33: 29,30 ; 42: 12,17$. From these sermons I could draw some conclusions regarding Calvin's thought on the providence of God.

Above all, we find a deep conviction and faith in the comprehensive sovereignty of God over all creation. Everything that happens, whatever it may be, finds some place in the eternal counsel of God. The power of evil, which we so often observe and experience, should allways be seen in the perspective of God's grace in Christ. His work of reconciliation will, without any doubt, overcome the powers of evil. The suffering of Christ is the fundamental reality for the faithful and obedient existence of man. Calvin strongly rejects every endeavor of man presumptuously to examine or even judge the hidden motives of God. He knows what he is doing and he may use whatever means he prefers for his particular purpose. In Calvin's exposition of Job there is 
undoubtedly a marked tension between a revealed justice of God and a hidden justice. And yet, occasionally it does happen that the light of revelation even breaks through the confines of God's hidden counsel.

Calvin did not endeavour to develop a theodicy. Yet, he does indicate certain reasons for God's 'peculiar' acts of providence. They could be a means of creating humility and obedience, or of bringing us back to ourselves through various afflictions. It is quite remarkable to note how Calvin in his sermons often deplores Job's impatience with and rebellion against his awkward situation. This he contrasts with the humility of David.

Calvin also addressed himself to the question of retribution in acts of providence, and came to the conclusion that it should rather be seen as a matter of human perception. Suffering, however changes perception. Only those who suffer, learn to understand what suffering is about. In no way should we regard affliction as an injustice done to us by God. Undoubtedly we deserve the afflictions we experience, while the opportunity to repent and trust God is nothing but grace. In the end, good will prevail over evil. Even now there is a quantitative prevalence of good over evil. Calvin clearly rejects every idea of determinism. Human responsibility should in no way be minimalized. The believer should unconditionally trust God in his providence. Give heed, and you will at once perceive that ignorance of Providence is the greatest of all miseries, and the knowledge of it is the highest happiness (Inst I.17.11).

It is noteworthy that Calvin's view of providence runs through his writings like a golden thread. It is also noteworthy that it does not occur only in his strictly theological writings, such as the Institutes, but that it keeps on surfacing in his more popular writings, such as his letters and sermons. In his understanding, the doctrine of providence had vast implications for the way in which people live their daily lives.

In a recent study on the providence of God in Calvin's correspondence (Potgieter 1991), I came to some interesting conclusions. I was able to indicate that this doctrine, which Calvin systematised in his Institutes, is remarkably contextualised in the many letters he wrote to various people. It is clear that in this difficult matter he wished to be led only by the revelation of God. This is especially apparent in the exegetical labour of his commentaries on different books of the Bible.

However, it is also clear that he applied himself to write in a very responsible manner about divine providence, especially when he applied it in his letters to particular situations in the lives of the addressees. This is especially evident in the letters of comfort he wrote. By emphasizing God's providence, he sought to communicate hope and comfort to people. As a result of his handling of the doctrine of providence in his correspondence and sermons, it acquires a therapeutic character. In this way he broke with the typically medieval idea of a blind fate, which he obviously rejected outright. On the other hand, he could not free himself from all sixteenth-century concepts. 
Amongst these are his distinction between the revealed will of God and his hidden will, his strong emphasis on the role of the church in the realisation of providence, and his use of symbolic language (Potgieter 1991:93f).

Saxer (1980:22) rightly showed that the doctrine of providence was not for Calvin primarily a dogmatic matter, but rather a motif running through our daily lives, indicating God's honour as the ultimate purpose of everything that happens.

It was tremendously important to Calvin that acceptance of and acquiesence in divine providence should be fully acknowledged as part of the daily service of God. This is precisely why it enjoys such prominence in his popular writings. Faith in God's providence must be sustained even if there is no obvious rationale for the troubles that assail us. All we can do is to humble ourselves before God and patiently wait until in his providence he ordains something good for us. And soon enough we will indeed see clear signs of this. Meanwhile we must be brave, in the knowledge that God is testing us with some form of tribulation, in order to give us even more opportunity to be serviceable to him (OG XX epist. 3947).

However, it is clear that the doctrine of providence was for Calvin not so much a matter for explanation, but far rather a confession. Therefore he often acknowledges that divine providence has on more than one occasion put him on a course which he did not envisage beforehand (OC XXI col. 21).

Calvin had the highest estimation of the total authority of God over everything in existence. Nothing whatever happens by chance or as a result of fate (Nielsen 1980:70).

In his Institutes Calvin deals fully with the subject of divine providence in Book I, Chapters 16-18. In outline, his view is that providence is God's deliberate and purposeful government of everything on earth. He is not merely the Creator, but also the Provider and Guide. This can all be based on the will of God. If the will of God is the true cause of all things, then his providence guides all that we think and do. However, this is applicable not only to those elected by God, who are led by the Holy Spirit, but also to the reprobate, who are subjected by providence to obedience to God's will (OC II col 170).

The will of God, in turn, is grounded in his goodness. Farley rightly points out that this view is not derived from a philosophical structure, but is deduced from God's mighty acts, to which Scripture bears witness (Farley 1988:153). 'What Calvin spells out so clearly for all to see is that it is not necessity or determinism but divine guidance that lies at the heart of a biblical and Reformed understanding of God's providential overruling' (Farley 1988:156).

Against this background I would now like to look at the way in which divine providence is dealt with in a number of Calvin's sermons on the book of Job. 


\section{THE SERMONS ON JOB}

Calvin preached on the book of Job on no fewer than 159 occasions (CO Vol 33-35). These sermons were delivered on weekday mornings from 26 February 1554 until March of the following year. It was a period in his life when Calvin himself experienced exceptional tension and distress on account of conflict with the city fathers of Geneva. On the one hand, these sermons testify to his sincere piety and humility before God. On the other, they are profoundly theological. In a sense he develops his doctrine of God extensively and lucidly. But divine providence also figures strongly, for, in common with many 16th century exegetes, Calvin read Job as a book on the theme of providence (Schreiner 1994:5). Indeed, throughout the sermons, more or less direct references are made to providence.

It was a time of religious, social and political upheaval, and because Calvin himself experienced the painful reality of religious persecution, his sermons on Job were extremely topical (cf Schreiner 1994:6). In many places in his writings Calvin appeals to his readers to trust in divine providence. Although it is often difficult, it is something that bears on one's salvation (cf Calvin's New Testament Commentaries, 7:141; Reardon 1975).

In the context of events which his congregation would have found hard to come to terms with or even to understand, Calvin tried to show them from Job's situation that they could merely confess that because they were unable to see the righteousness of God, they had to hold on to the knowledge that while they now saw in a glass darkly, they would one day also see the providence of God as it really was (Schreiner 1986).

Therefore it is not strange that in a time of religious persecution these sermons were regularly read in many churches in France. They were also a source of comfort and encouragement to many families and meant a great deal to those who were persecuted, including Admiral De Coligny (Woudstra 1984:345).

For the purpose of this paper it was necessary to make a selection. I did this by trying to determine which Scripture references from Job are regularly quoted in standard theological works on the doctrine of providence. I then looked specifically at the sermons of Calvin on these particular Scripture passages.

In order to be able to draw conclusions, I have at each stage allowed Calvin to speak for himself in an appropriate selection from a particular sermon. What he says will then be systematised by way of a summary, and so a total picture will ultimately emerge.

The role of Satan in Job's tribulation is often quoted in theological works on divine providence, especially with reference to Job 1:12: “"All right”, the Lord said to Satan, "everything he has is in your power, but you must not hurt Job himself"'. On this score Calvin says: 
At the first blush one might well marvel why God gave his servant over to Satan's pleasure .... It might seem as if he makes sport with us as with a tennis ball. But let us mark that when God grants Satan this thing, he does not do it for Satan's sake but because he has thus ordained it for his own purpose. He is not moved by Satan's request but long before Satan uttered a word, he had already determined to chastise his servant for a good cause ... Although Satan seeks to cast us into despair, let us be sure that God's fatherly love towards us is such that he supports us like his little babies and that our enemy is not given the liberty over us that he would like to have ... God loves us so tenderly that he desires nothing but to bring us home again ... We must be fully persuaded that the devil is under God's control and can do nothing without his permission. Furthermore, he is, as it were, God's executioner to carry out his judgments and punishments upon the wicked. He is also the rod by which God chastises his children.

In short, the Devil is obliged to be the instrument of God's wrath and of his will. Yet there is this limitation: that Satan may not touch Job's person.

What are we to do? We must walk in humility, contenting ourselves to know only in part until full knowledge is disclosed to us at the latter day ... Let us mark that when God gives Satan such sway over the faithful, it is only for a little while ... God had another purpose: to bridle his servant so that he did not forget himself and exalt himself too much. For this reason he was buffeted.

Another Scriptural reference that is often noted is Job's acquiescence in 1:21: The Lord gave, and now he has taken away. May his name be praised!

In this regard Calvin says:

If God allows us to enjoy any benefit for two or three days, we think he does us a great wrong if he takes it from us again and we complain against him for doing so ... So we must consider what is meant by this saying: 'The Lord gave, and now he has taken away' and acknowledge the Lord's authority over us to grant us benefits for our enjoyment, but also to take them away at any time as he pleases ... Whenever we think upon the goods of this world, we must always bear in mind that we have 
received them from God ... It is easy to say that God has given us all that we possess, but then we think that God should have no further right of disposal. Nothing must change; he must leave us alone ... What is the meaning of the confession that we hold all of him if he may not touch anything?

What he is saying here is that God does not wrong us in the least if he does not always let things go equally well with us. There is nothing to which we can lay claim as our inalienable right. Everything is grace.

It is striking that Calvin does not emphasise only the qualitative of God's gifts, but also the quantitative. He constantly uses words like number (il est vray que quand nous aurons conte, $\mathrm{CO} 33-35$, sermon $\mathrm{x}$ ) or count ( $q u$ 'il n'y a ne nombre ne mesure, $\mathrm{CO} 33$ 35 , sermon $x$ ) in this regard. What we experience as adversity is always overshadowed by the benefits God bestows. In this connection Calvin says with reference to Job 2:10 (When God sends us something good, we welcome it. How can we complain when he sends us trouble?)

God bestows so many benefits upon us; shall we not endure evil at his hand when it pleases him? Ought he not to have superiority over us and punish us when it seems good to him? ... Above all, we must mark the gracious gifts which we continually receive at his hand. Let us count well, so we may confess with David, 'Oh Lord my God, your wonderful works are more than can be numbered' (Ps. 40:6). Why? Because God's goodness is a bottomless pit that we cannot contemplate without amazement. If we consider how God has shown himself a father to us from our birth, and even before our birth, must we not be confounded before we have discovered even a hundredth part of his goodness to us? Seeing then that God's graces are innumerable and by no means to be comprehended, why should we not accept the adversities he sends us? Even if we were afflicted much more than we are, God's benefits would far surmount all the afflictions that we can suffer at his hand.

Calvin also emphasises that we must not hesitate to ask why God sends us tribulation. If he is disciplining us on account of our sins, he is acting in our interest as Job 5:17 and 18 teaches: 
Happy is the person whom God corrects!

Do not resent it when he rebukes you.

God bandages the wounds he makes;

his hand hurts you, and his hand heals.

Calvin says:

God wishes to be kindly towards us; things go well with us. Even when he chastises us, he does not use such sharpness that we no longer feel his goodness and mercy ... We must love him not only when he does good to us, but even when he chastises us for our sins.

In Job 14:5 there is direct reference to God's providence and disposing over human life:

The length of his life is decided beforehand the number of months he will live.

You have settled it, and it can't be changed.

In this regard Calvin says:

It is a cause for great comfort that our life is in God's hand. Why are men so fearful that they dare not stir a finger without trembling? They do not know that God has them in his keeping and that he may take them out of this world as he has put them into it. If we were thoroughly persuaded of this, it is certain that we would calmly pursue our way and not be as tormented as we are. So much the more then we ought to take this teaching seriously: that God has determined our days. However, we must keep a mean in this matter. Although we may have peace of mind because our life is in God's hand, yet we must not rashly endanger ourselves, but walk advisedly as God commands us.

There are fanatics who, hearing that a man's days are numbered and that we cannot lengthen or shorten our lives, say: 'Very well then, if I do all that comes into my head, it's all the same; he that is born to be hanged will never drown' ... These despisers of God say that we may 
shut our eyes and pass through fire and water because God has determined our days. But this is not what Scripture means when it says that having put us in this world, God well knows how long he will leave us in it and that we are in his hand. We will depart from here when it pleases him, as we read in Ps. 90:3 ... If we stay on the road that he shows us, we are guarded by him and his angels. Then we may be assured and courageous when God will have us enter any danger. We see in our own time the state the poor Christians are in: they are like sheep in the jaws of wolves. But if we go about excusing ourselves from serving God and do not want to confess our faith because it cannot be done without putting ourselves in jeopardy, do you think that God will accept such a foolish excuse? No. For he has our life in his hand. Let us trust in him to keep us as he is good and faithful. If it pleases him that we must suffer, it will not be apart from his will, and then he will give us strength and power. So we must apply what is said here to ourselves; otherwise it will go with us as with many others who shrink away and forsake the service of God because they shun the cross ... If need be, we must not shy away from entering into death, since we know that, whatever they may attempt or practise against us, men are able to do nothing.

Thus Calvin explicitly condemns the blasphemous concept of determinism, namely that we can do as we choose since everything is in God's hands and he will make happen whatever has to happen, as if we do not have the task of living our lives with great responsibility. On the other hand, it is precisely the person who lives responsibly and obediently before God who may count on the preserving presence of the Lord and on his merciful support in times of trial and suffering.

Another pericope that is often quoted in relation to the doctrine of providence is Job 31:1-4:

I have made a solemn promise

never to look with lust on a girl.

What does the Almighty God do to us?

How does he repay human deeds?

He sends disaster and ruin

to those who do wrong.

God knows everything I do;

he counts every step I take. 
In his sermon Calvin says:

Job declares that he has lived in a holy and upright manner before God. He had not even looked on a girl to desire her. He must have thought it strange to be afflicted by God's hand although he had lived his life as we see here. And yet it was good that he knew the end and cause why God visited him so.

What Job does here is to declare that he has served God faithfully and that his enduring of such grievous and excessive miseries is not on account of any offence that he has committed, but from some secret reason known to God, which men can neither know nor discern.

In verses 2 and 3 Job says that from heaven God justly punishes the wrongdoer, but then, in verse 4 , he follows this by saying that God watches over my paths and counts every step I take. With reference to this he presents divine providence as a warning we must always bear in mind. Calvin continues:

God examines and knows all my ways. Because he is the judge of all men, I cannot escape his hand. Does God not see everything I do? ... Notice how Job expresses himself when he says that God counts every step that he takes. This implies that God does not look at him from a distance and does not see only things that are apparent to the world. He looks closely and sharply at all our actions and notes and marks each one of them. His sight is not dimmed and he does not view things at random, but marks, counts and numbers all things, so that nothing escapes him and nothing is forgotten by him. Now then, I pray you, do we not have better cause to consider our ways and count our own steps, when we see that all is present before God? Why is it that men scarcely know a hundredth part of their sins? And why can some men commit the same fault a hundred times a day and scarcely consider it? It is because we do not think that God watches us, that nothing is hidden from his sight and that he does not forget any of our actions and thoughts ... Everything will come to light. What must we do? We must look more closely at ourselves than we have been wont to do ... Let us plead guilty before God and in sorrow for our sins confess with David that it impossible for us to know all our faults. And therefore let us pray to God who is good 
that when he has looked upon the faults and sins which we ourselves cannot see, it may please him to blot them out. So we will repose the trust for our welfare and salvation in nothing other than his receiving of us in mercy for our Lord Jesus Christ's sake, and know ourselves to be washed clean with the blood which he has shed for our redemption.

In this sermon Calvin confirms two points made elsewhere. The first is that there is a hiddenness in what God does that is too deep for our insight and understanding. The other is that our responsibility for our actions is not separable from divine providence.

However, there is also a third aspect that does not emerge so clearly elsewhere, namely the Christological. Here Calvin establishes a complete linkage between providence and the Gospel and salvation in Christ. Anyone who is in Christ has everything, even though he experiences many afflictions in his life.

Job 33:29 and 30 is also a popular Scriptural reference in theological texts on providence:

God does all this again and again;

he saves a person's life, and gives him the joy of living.

Calvin comments as follows:

We have seen how God provides for our welfare. We are wretched creatures and if he on his part did not remedy our vices, there would have been no hope for us. We would have been utterly lost and forlorn if God did not have pity on us. And the means of his doing so has been made clear to us: he teaches us to receive his grace, sometimes by the chastisement he gives us, sometimes by afflictions and heavy blows of his rod. If he sees that we are dull and slow, he strikes us harder, compelling us to come to him because we can hold out no longer. Then he comforts us, so that we may come to him, call upon him and know his favour. Having experienced his grace, we will acknowledge it before men and so have greater certainty in ourselves and also bring greater certainty to our fellows ... If we will not learn, God keeps on chastising us in order to draw us to him by humbling us and comforting us again. If this were done but once, we would soon forget it and return to our 
own nature and we would not have the strength to walk in the way that becomes us.

So Calvin seeks to stress once more that God does not visit affliction on us for no reason. We must see his judgements as a means to bring us to greater obedience. And even if it happens more than once, it is necessary since our sinful nature keeps on asserting itself.

In the final chapter of Job the dramatic perspective is offered that God accomplishes his own good purpose by means of all the tribulations:

Job 42:12: The Lord blessed the last part of Job's life even more than he had blessed the first ...

verse 17: And then he died at a very great age.

In his sermon, Calvin says inter alia:

It is true that it does not commonly happen that God doubles his benefits towards those who have been afflicted. God does not deal with all of us in the same way. He knows what is good for every man and it behoves us to accept what we receive as it pleases God to bestow it, even as the head of a family knows what is good for his household. Yet we may take it as a general rule that God will not only bring our afflictions to an end, but will also make them serve our welfare. So we shall see that he does not forget us, even when he afflicts us. Rather he showed himself to be a father to us by not letting us fall too fast asleep in this world. As for the temporal blessings, we may well take them also as God sends them. However, we must not lose sight of what is most important: even if there were nothing else apart from our assurance of God's goodness and of having received his help and that our faith endured under affliction - is that not already a great deal? The man who knows how available God's favour is to help us in our need sees in affliction that God so strengthens us by his Holy Spirit that he can patiently bear the affliction. And when he is delivered, he knows that it is from God and that God will never fail him. Even if we only see the help that God gives us, and his working in us by his Holy Spirit that enables us to stand firm, and his teaching us by experience that he is ready to help us at all times, it would already be of inestimable benefit. But there is yet more, namely that God makes us see how weak we are, though we 
did not know this before, and thus we are encouraged to call upon him ... When God has cast us to the ground and we are brought low, it is to make us cleave to him and to give us a richer experience of the spiritual welfare prepared for us. So we must let God deal with us as he sees fit. However we fare, let us assure our fellows that the end will always be happy. And, truly, if our afflictions serve to bring us to the glory of our Lord Jesus Christ, and when we are taken out of this world, we shall be with the Son of God and his angels, ought we not to honour them? And even though it is hard for us, we must rejoice continually and yield thanks to God, especially when he delivers us out of our present miseries.

\section{CONCLUSIONS}

The sermons examined in this paper give proof of Calvin's remarkable insight into the providentia Dei.

Above all, there is the premise of faith of God's all-encompassing hold on created reality. Literally everything has a meaningful part in the Counsel of God. The apparent power of evil - with all the suffering and tribulation it brings in its train is indeed only apparent. When it is set in the perspective of God's grace shown to us in Christ, as it must be set, the good of his redemptive work triumphs over the evil of our experience. Calvin has a traditional approach to suffering: it is definitive of the believer's life and must be understood in a wider biblical and Christological context: Christ's suffering is the fundamental reality of faithful and obedient existence (Schreiner 1994:95).

We must refrain from presumptuously trying to fathom God's hidden motives. In his wise judgement he uses whom and what he wills to achieve his purpose for creation.

In connection with the hidden counsel of God, it might be noted in passing that in his treatment of the book of Job, Calvin followed the Thomist tradition by identifying the literal interpretation of Job with the doctrine of providence (Schreiner 1994:4). However, Schreiner points out that Calvin differs from Aquinas in that the inscrutability of providence receives greater emphasis and that he describes Job's suffering in terms of the hiddenness of God (Schreiner 1992:135). In God there is both a revealed justice and a hidden justice, and with our insight we can never comprehend the latter (cf Bohatec 1936:146-7).

Calvin's exposition of Job is characterised by a recurring tension between divine revelation and divine hiddenness (Schreiner 1994:94). Yet it is as if the light of revelation constantly breaks through from the hiddenness of God. 
Although Calvin does not develop a theodicy, he indicates several reasons for the 'alien' actions of God. These may be a means of moving us to humility and obedience and especially of bringing us back to him through adversity. It is striking how, time and again in his sermons on Job, Calvin deplores Job's impatience and outbursts, opposing to them David's humility and his acknowledgement that his afflictions were merited and necessary (Schreiner 1994:101, cf CO 33:151-53, 269, 666; CO 34:27778, 350; CO 35:114, 199-200,508). But sometimes God's action is also just retribution. Schreiner draws attention to the remarkable comparison that Calvin keeps drawing between Job and David. Calvin is keenly aware that in the stories of Job and David two kinds of affliction co-exist: retributive and non-retributive suffering (Schreiner 1994:99). However, Calvin saw the problem of retribution in the doctrine of providence as one of perception: it cannot be discerned by the human eye. But suffering brings a change of perception. The one who suffers discovers truths that cannot be understood by those who do not suffer (Schreiner 1992:141f).

In no way can it be said that God wrongs us when we sometimes encounter grief on our road. The retributive aspect of it is deserved, but the opportunity to humble ourselves and return to God is sheer grace. For those who belong to God the end will always be good. Indeed, even now we may acknowledge that there is a quantitative prevalence of good over evil in our lives. Hereafter we will also know the answers to our questions.

Accordingly divine providence must not be understood as a general matter. Although there is a broader perspective to it, it is essentially directed to the particular circumstances of the individual. By no means may divine providence be seen as deterministic. Calvin repeatedly stresses human responsibility. The believer may, can and must put his trust in God's providence. Therefore we must know that the greatest misery we can endure is not illness but to be forgotten by God, that he no longer hears your prayers (CO 33:683), that he remains hidden to you. Or, as Calvin puts it so strikingly in the Institutes: 'Give heed, and you will at once perceive that ignorance of Providence is the greatest of all miseries, and the knowledge of it the highest happiness' (Institutes, 1.17.11, tr by Henry Beveridge) ${ }^{1}$.

\footnotetext{
End Notes

1 The English translations of Calvin are based on: Calvin. Sermons on Job, facsimile edition of Arthur Golding's 1574 translation. Edinburgh: Banner of Truth Trust, 1993. The bibliographical details relating to the Institutes are as follows: Calvin. Institutes of the Christian Religion, translated by Henry Beveridge, 1962 reprint in two volumes. London: James Clarke.
}

\section{Works Consulted}


Baum, C, Cunitz, E \& Reuss, E, (reds) 1863-1900. Ioannis Calvini opera quae supersunt omnia (Corpus Reformatorum; vol 29-87), Vol 59, Brunsvigiae (=OC).

Bohatec, J 1936. Gott und die geschichte nach Calvin. Philosophia Reformata 146147.

Calvin, John 1958-63. New Testament commentaries. Grand Rapids: Eerdmans.

1993. Sermons on Job, facsimile edition of Arthur Goding's 1574 translations. Edinburgh: Banner of Truth Trust.

- Institutes of the Christian Religion, tr by Henry Beveridge, 1962 reprint in two volumes. London: James Clarke.

Farley, B W 1988. The providence of God. Grand Rapids.

Nielson, W 1980. The theology of Calvin. Grand Rapids: Baker.

Potgieter, P C 1991. The providence of God in Calvin's correspondence, in: Calvin, Erbe und Auftrag: Festschrift für Wilhelm Neuser zu seinen 65 Geburtstag. Herausgegeben von Willem van't Spijker, 1991. Kampen: Kok Pharos.

Reardon, P H 1975. Calvin on providence: the development of an insight. Scottish Journal of Theology 517-533.

Saxer, E 1990. Vorsehung und Verheissung Gottes. Zürich.

Schreiner, S E 1986. Through a mirror dimly: Calvin's sermons on Job. Calvin Theological Journal 21/2, 175-193.

Schreiner, S E 1992. Why do the wicked live? in Ed Perdue, L G \& Gilpin, W C (eds), The voice from the whirlwind. Nashville: Abindon.

1994. Where shall wisdom be found? Calvin's exegesis of Job from medieval and modern perspectives. Chicago: Chicago University Press.

Woudstra, M H 1994. The use of 'example' in Calvin's sermons on Job, in Bezield. verband. Kampen: Van den Berg. 